\title{
Subtrochanteric fracture in a near term pregnant female in the back drop of COVID-19 pandemic: A triple trouble pregnant with peril all along
}

\author{
Arun Kumar Sharma ${ }^{1}$, Divyanshu Goyal ${ }^{2}$, Ramesh C Meena ${ }^{3}$, Mahesh C Bansal ${ }^{4}$, \\ Rajesh Kumar Sharma ${ }^{5}$, Sanjeev Kumar ${ }^{6}$
}

${ }^{1}$ Assistant Professor, ${ }^{2}$ Senior Resident, ${ }^{3,4}$ Professor, Department of Orthopedics, SMS Medical College, Jaipur, India, ${ }^{5}$ Medical Officer, Primary Health Centre, Dausa, Rajasthan, India. ${ }^{6}$ Assistant Professor, Department of Orthopedics, King George Medical University, Lucknow, India

\section{A B S T R A C T}

Outbreak of severe acute respiratory syndrome corona virus was first reported in Wuhan province in China. By February all hell broke loose in Europe and other continents. Spread of virus in India with 1.38 billion population posed an unprecedented challenge to its health care system. We hereby report a rare case of subtrochanteric fracture of femur in a near term ( 35 weeks) pregnant female who was treated at our tertiary care center in the times of Covid-19. Combination of pregnancy and Subtrochanteric femoral fracture is a double trouble with high morbidity and mortality and in time of Corona pandemic it became a unique challenge where two lives were at risk. Here we share our experience of dealing this case with multidisciplinary approach and sticking to our clinical sense as literature for Covid-19 pandemic is barely 4 months old and devoid of any guideline for such cases so far.

Key words: Near term pregnancy; subtrochanteric femur fracture; Covid-19 pandemic; multidisciplinary approach

\section{Access this article online}

Website:

http://nepjol.info/index.php/AJMS DOI: 10.3126/ajms.v11i4.29047

E-ISSN: 2091-0576

P-ISSN: 2467-9100

Copyright (c) 2020 Asian Journal of Medical Sciences

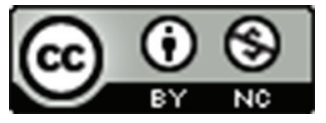

This work is licensed under a Creative Commons Attribution-NonCommercial 4.0 International License.

\section{INTRODUCTION}

Wuhan province first reported a pneumonitis outbreak at the year end, which was later diagnosed to be Severe Acute Respiratory Syndrome corona virus two [SARSCov-2]. ${ }^{1}$ It was unsuccessfully contained by local shut down but by then the novel Covid-19 virus had escaped like a horse bolts the stable. ${ }^{2}$ By April our country was already in first phase of nationwide lockdown, which coincided with the case described. ${ }^{3}$

Orthopedic injury in pregnancy is a risky subgroup with an incidence of $1 \% .{ }^{4}$ Pelvi acetabular fracture has the highest morbidity and mortality associated in term pregna Mahesh ncy. ${ }^{5,6} \mathrm{~S} / \mathrm{T}$ (Subtrochanteric) femoral fracture in pregnancy secondary to trauma is a rare subgroup since most of the reports available are associated with non-traumatic fracture of neck of femur. Most of these proximal hip fractures have been associated with pregnancy and lactation associated osteoporosis (Table 1). ${ }^{7}$ We are reporting this case for being first in literature and to highlight the unique challenges, Covid19 pandemic is posing to health care system. Pregnancy and trauma is double trouble ${ }^{8}$ and such cumulative triple trouble (combination of 


\begin{tabular}{|c|c|c|c|c|c|}
\hline Author & $\begin{array}{l}\text { Year of } \\
\text { publication }\end{array}$ & $\begin{array}{l}\text { Time of pregnancy, } \\
\text { Uni or bilateral }\end{array}$ & pathology & Treatment & Result \\
\hline Ismail Sahan & 2019 & Bilateral, post partum & TOP, epilepsy & Bilateral short stem THR+ & \\
\hline Samantha Tayne & 2019 & $\begin{array}{l}\text { Unilateral, post partum } \\
\text { presentation, delayed } \\
\text { diagnosis }\end{array}$ & $\mathrm{TOP}^{*}$ & THR+ & Good one year follow up \\
\hline $\begin{array}{l}\text { Mohammad } \\
\text { JafarEmami }\end{array}$ & 2012 & 6 month, bilateral & TOP $^{*}$ & $\begin{array}{l}3 \text { month delayed } \\
\text { diagnosis\& treatment, } \\
\text { Bilateral Hemi-arthoplasty } \\
\text { as two stage procedures }\end{array}$ & Good \\
\hline Kalender AM & 2010 & $\begin{array}{l}\text { Post partum diagnosis, } \\
25 \text { day delay, bilateral }\end{array}$ & $\begin{array}{l}\text { Primary hyper } \\
\text { parathyroidism,TOP }\end{array}$ & $\begin{array}{l}\text { Cannulatedcancellous } \\
\text { screw fixation }\end{array}$ & $\begin{array}{l}\text { No AVN } \\
\text { ++although delayed } \\
\text { presentation by } 25 \text { days }\end{array}$ \\
\hline Janos Csotye & 2010 & Bilateral, 35 week & TOP & $\begin{array}{l}\text { Cannulatedcancellous } \\
\text { screw fixation }\end{array}$ & $\begin{array}{l}\text { Failed osteosynthesis, } \\
\text { staged THR after } \\
6 \text { months }\end{array}$ \\
\hline Gurreyl & 2010 & Unlateral,38week & TOP & $\begin{array}{l}\text { Cannulatedcancellous } \\
\text { screw }\end{array}$ & AVN++ of femoral head \\
\hline Wills-owen CA & 2008 & $\begin{array}{l}\text { Bilateral, third trimester, } \\
\text { diagnosed post partum }\end{array}$ & TOP & Bilateral DHS post partum & Good result \\
\hline Aynaci & 2008 & $\begin{array}{l}6 \text { days post } \\
\text { partum, Bilateral } \\
\text { acetabular\&femoral neck }\end{array}$ & TOP & Bilateral THR & \\
\hline Munker R & 2007 & $\begin{array}{l}\text { Bilateral, } 35 \text { weeks, } 4 \text { week } \\
\text { delay in diagnosis }\end{array}$ & TOP & $\begin{array}{l}\text { One side THR } \\
\text { One Side Cannulated }\end{array}$ & Good result \\
\hline $\begin{array}{l}\text { Z } \\
\text { OrthopIhreGrenzgeb }\end{array}$ & & & & Screw & \\
\hline Cohen & 2007 & Unilateral,29 month & TOP & $\begin{array}{l}\text { Cannulatedcancellous } \\
\text { screw }\end{array}$ & $\begin{array}{l}\text { Good result till } 2 \text { year } \\
\text { follow up }\end{array}$ \\
\hline Leistedt & & Bilateral, 36 months & TOP & $\begin{array}{l}\text { THR one side, } \\
\text { Conservative } C / L^{* *}\end{array}$ & \\
\hline Wood & 2003 & $\begin{array}{l}\text { Unilateral } 5 \text { month } \\
\text { postpartum }\end{array}$ & TOP & $\begin{array}{l}\text { Osteosynthesis With } \\
\text { screw \&Bone grafting }\end{array}$ & \\
\hline Wattanawong & 2003 & Bilateral, $3^{\text {rd }}$ trimester & TOP & $\begin{array}{l}\text { Initial conservative, failed- } \\
\text { bilateral THR after } 1 \text { year }\end{array}$ & $\begin{array}{l}\text { Reported Good for } 2 \\
\text { year follow up }\end{array}$ \\
\hline Fokner & 1997 & $\begin{array}{l}\text { Unilateral, Third } \\
\text { trimester, diagnosis } \\
\text { delayed by } 3 \text { weeks }\end{array}$ & TOP & $\begin{array}{l}\text { ORIF } 3 \text { weeks after } \\
\text { fracture \&2 weeks } \\
\text { postpartum }\end{array}$ & \\
\hline Junk & 1996 & $\begin{array}{l}\text { Unilateral, } 2 \text { week } \\
\text { postpartum }\end{array}$ & TOP & Screw and plate & \\
\hline Fingeroth & 1992 & Unilateral 36 week & TOP , seizure & Screws & \\
\hline Gouin & 1992 & 2 week postpartum & TOP & Bipolar hemi arthroplasty & \\
\hline Brodell & 1989 & Bilateral, & TOP & $\begin{array}{l}\text { a. conservative } \\
\text { b. conservative }\end{array}$ & $\begin{array}{l}\text { One side required } \\
\text { osteotomy }\end{array}$ \\
\hline Curttis & 1959 & Unilateral, postpartum & TOP & $\begin{array}{l}\text { Conservative, as } \\
\text { treatment was not } \\
\text { established then }\end{array}$ & Good result \\
\hline
\end{tabular}

*transient osteoporosis of pregnancy+ total hip replacement, ++avascular necrosis, ** contra-lateral

Subtrochanteric Fracture with pre-term pregnancy while community corona spread was and still on the rise) is unheard of in literature. Hence, we are further discussing importance of multi-disciplinary coordination, prioritizing quick decision making and doing more than one procedure together to prevent multiple admissions and thus preventing enhanced chances of exposure of Covid -19 to high risk group.

\section{CASE REPORT}

A 28-year-old female, Gravida 4 Para 3 reported to emergency in our tertiary care hospital. She had an unusual trauma history of fall from horse, with inability to stand, pain and swelling in left thigh region. History revealed 35 weeks of pregnancy and was going for scheduled obstetrician visit while sustaining this injury. India was in a country wide lock down state imposed from 24 March 2020 onwards so no modality of transport was available from her village. ${ }^{3}$ Her family managed her pillion ride on horse with her husband and she sustained a fall while mounting on the horse. Suspecting hip injury and anticipating risk to the fetus, the ambulance was called from the nearby district hospital and considering a double trouble of fracture and pregnancy, the patient was referred to our center after 
initial resuscitation. X-rays was done at district hospital revealed sub-trochanteric facture of left femur. There was no comorbid illness, and she had an uneventful pregnancy until this trauma. There was no evidence of neurovascular deficit or compartment syndrome, and it was closed fracture. X-ray showed subtrochanteric fracture classified as 32C1.1 type according to the Arbeitsgemeinschaft fur Osteosynthesefragen(AO) (Figure 1). The fracture was temporarily stabilized with a Thomas splint. After orthopedic survey, the obstetrician evaluated the fetus and the mother. According to the Obstetric ultrasonography (USG), no pathologies were detected. Previous USG report from patient record showed healthy normal fetus. Her hemoglobin levels and other laboratory parameters were normal. Her expected date of delivery according to previous USG was nearing and was 5 weeks to go, so there was a dilemma for further management. Broadly we deliberated upon three management options and analyzed risk benefit ratio of each.

1. Managing hip fracture conservatively till EDD (expected date of delivery).

2. Fixing $\mathrm{S} / \mathrm{T}$ fracture and then shifting to obstetrician team.

3. Fixing $\mathrm{S} / \mathrm{T}$ fracture and doing caesarean section under same anesthesia.

Option 1- Non operative modality for fracture sub trochanteric femur has its own shortcomings with deep vein thrombosis, nonunion, and poor functional outcome as usual complications. Pregnancy being hypercoagulable state, the prolonged bed rest for two weeks could have added risk of DVT and other morbidities.'

Option 2 was associated with anesthesia twice and exposing patient to double dose of perioperative

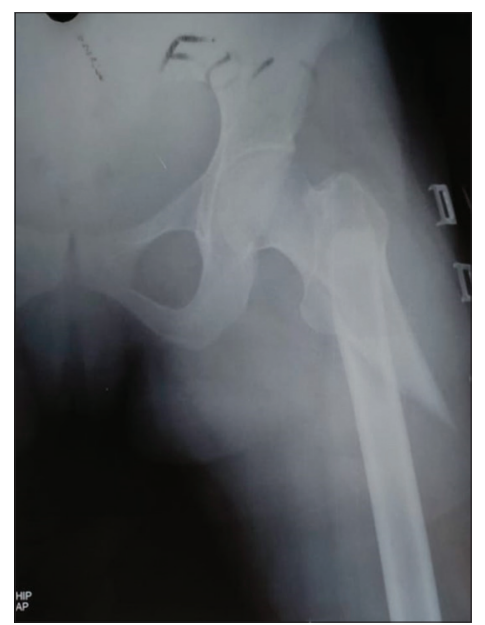

Figure 1: Preoperative X-ray showing subtrochanteric fracture of left femur anesthetic, antibiotic and anticoagulant drugs. Surgical management of a pregnant patient's injury should be as short in duration as possible while maintaining optimal care. ${ }^{10}$ This decision was all the more important in pandemic scenario, where prolonged hospital stay was also fraught with higher exposure chances to both mother and fetus. Heath care decision makers and epidemiologist were expecting a peak which was happening in Europe at that period of time. Therefore, as per standard operating procedure (SOP), to reduce the likelihood of exposure of COVID-19 to existing inpatients; to free up beds for admission of suspect COVID-19 cases and ensure manageable workload, early discharge of non-corona patients was of paramount importance.

The third option involved a multidisciplinary approach and a single stage surgery, which was agreed upon by consensus decision. Further deliberation included which implant to use. Intra-medullary PFN (proximal femoral Nail) being load sharing implant allows early weight bearing therefore preferred usually in $\mathrm{S} / \mathrm{T}$ (subtrochanteric) fractures. In current situation, where implant suppliers were not available due to country wide lockdown and withheld operations all over the state amidst anxiety and uncertainty, we had to make do with DHS (dynamic hip screw) implant available in hospital store. In our experience although DHS is extramedullary load bearing implant but it is also less jig and position dependent. Anesthesia team which was accustomed with both orthopedic and obstetric anesthesia was called and neonatology team was informed. An epidural anesthesia was preferred over general anesthesia and spinal anesthesia. Spinal anesthesia was avoided as it may lead to sudden loss of sympathetic tone resulting in bradycardia and hypotension. Third generation cephalosporin was given intravenously as prophylactic antibiotics. Obstetric team performed LSCS (lower segment Caesarean section) first and newborn was shifted to neonatal ICU. Thereafter orthopedic team performed open reduction with dynamic hip screw fixation with 7-hole locking side plate [Titanium 135-degree Dynamic hip screw and plates, Sharma implant ltd]. This patient was administered analgesics and cefuroxime. Moreover, for corona prophylaxis, (hydoxychloroquine 200mg 2 tablet on day 1 then 2 tablets weekly + tablet Vitamin B complex daily and tablet Vitamin $\mathrm{C}$ daily) were prescribed to mother as per government advisory. ${ }^{11}$ On day one post-surgery, she was mobilized, permitting partial weight-bearing with crutches. She was kept in separate room while newborn was kept in newborn ICU under neonatology team. Her husband was taught about physiotherapy part and rehabilitation as regular physiotherapist visit 
was unforeseeable during home stay. Two days after surgery, the mother and newborn were examined by obstetrician/orthopedic surgeon and neonatologist and was found to be deemed fit for discharge. Due to changed standard operating protocols and ground realities at COVID-19 pandemic, it was decided to follow up the patient telephonically and hospital follow up was kept only monthly. To break the chain of transmission, it was nationwide policy then, to cut short follow-up visits to hospital and use of telemedicine and technology wherever feasible. Patient got her suture removal done by surgeon at district hospital (a non-COVID center) and brought to follow up at our center at 4 weeks. Fracture union progress was satisfactory and both mother and infant were healthy. Next follow up was planned on 3-month post-surgery. Till then patient attendant were provided with telephone numbers of primary obstetrician/ orthopedic surgeon who conducted respective surgeries so that weekly

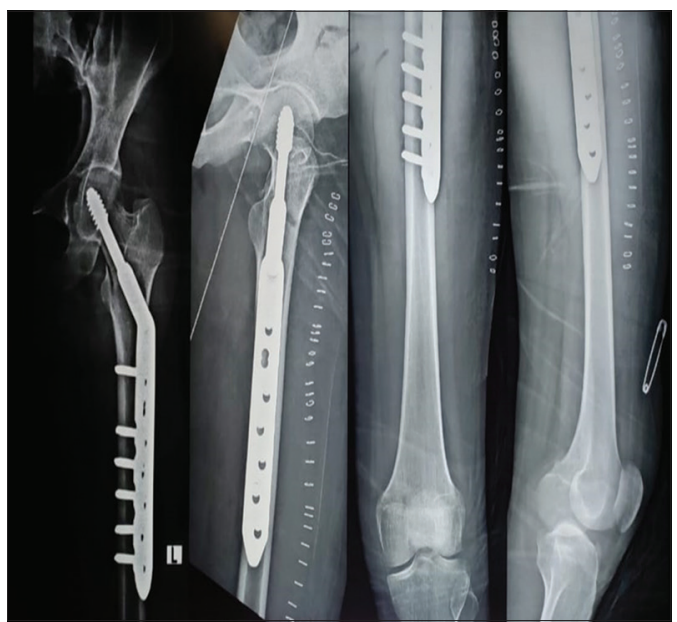

Figure 2: Post-operative $\mathrm{X}$-ray showing satisfactory reduction with dynamic hip screw (7 Hole with locking side Plate) progress could be assessed and/or contact could be made in emergency.

\section{DISCUSSION}

Trauma is the most common causative factor of non-obstetrical maternal death and resultant intrauterine fetal death. The most common etiology of trauma in pregnancy includes motor vehicle accident, fall, assault, and other injuries. ${ }^{12} \mathrm{We}$ conducted PubMed/Medline, Scopus, EBSCO, HMIC, Embase, Hinari and Cochrane data base search with keywords "pregnancy and femoral fracture", "pregnancy \& hip fractures"\& "Pregnancy \& subtrochanteric fractures". The keywords we used were the one, by which any relevant case report described previously could be searched in literature. We came across total of 4 case reports describing 6 cases of traumatic fractures and one associated with pathological femur fracture during pregnancy (Table 2). ${ }^{13-15}$ To the best of our knowledge, this is first case of subtrochanteric fracture in near term pregnancy in English literature. This is also the first case where Caesarean section and Subtrochanteric femoral fracture fixation has been done in same sitting. Backdrop of COVID pandemic with overburdened health care system gave it an unprecedented uniqueness. Fall from horse in $21^{\text {st }}$ century leading to such injury is rarest of rare phenomenon, which could be attributed to unprecedented lockdown leading to complete halt of every possible mode of public transport in the first week of lockdown, which India was facing for the first time since ages.

Country wide lockdown reduced usual road traffic accident, but it brought forth unusual trauma scenarios. It was a

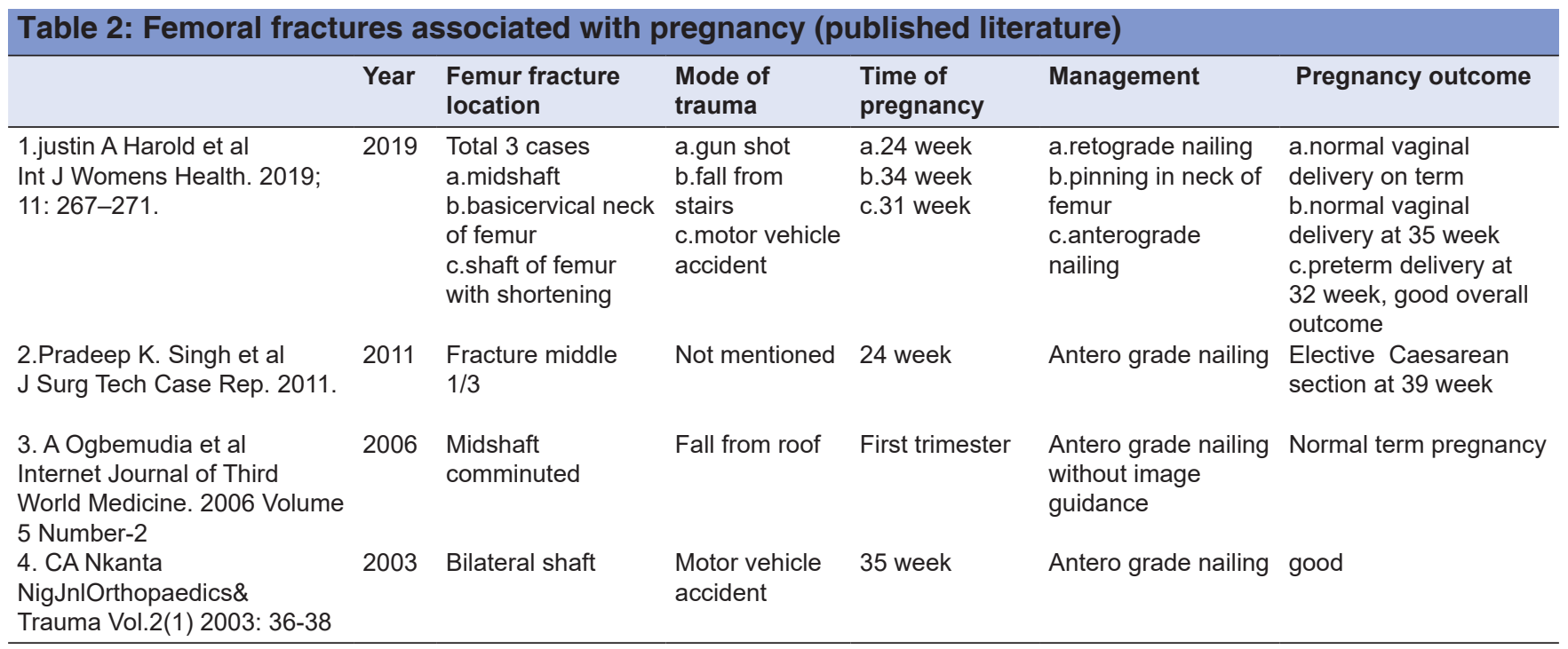


challenge in decision making also as COVID-19 testing was not mandatory for asymptomatic case in our hospital and testing resources were diverted to hot pockets of the city. COVID-19 being 2 month old in India that time, there was no clear cut guideline how to treat such cases in a tertiary care center which was also COVID-19 referral center at the same time.

We consider our strategy an amalgamation of evidence and ability of quick decision making in the background of covid-19 pandemic. Our city reporting the highest COVID-19 positive cases in tier 2 cities of India and our hospital being the only referral center for COVID positive cases that time, made managing such cases an unprecedented challenge. Our experience should come handy for the readership while dealing with orthopedic trauma at full term pregnancy in such pandemic or other.

\section{WHY THIS CASE REPORT IS SO EXEMPLARY?}

When routine modalities of transport were stopped during country wide lockdowns, these unusual times bring unusual mode of trauma (fall from horse) and subsequent pathologies (subtrochanteric fracture in near term pregnancy never described in literature in backdrop of menacing COVID-19 pandemic.

Secondly, patient with multiple pathologies like this case which is reported, requires multidisciplinary approach and swift management to reduce hospital stay and facilitating early discharge for efficient use of hospital resources to keep menace of pandemic at bay and reduce risk of exposure to both mother and fetus in hospital environment.

\section{CONCLUSION}

1. When routine modalities of transport are stopped during such lockdowns, these unusual times are bringing forth unusual mode of trauma and subsequent pathologies.

2. Patients with multiple pathologies like this case, require multidisciplinary approach and swift management to reduce hospital stay and facilitating early discharge for efficient use of hospital resources to keep menace of pandemic at bay and reduce risk of exposure to both mother and fetus in hospital environment.

\section{Ethical issues}

Written informed consent was taken from patient for every intervention and procedure. Patients also gave their consent for the use of their personal data and clinical outcomes for scientific researches. All guidelines as per protocol laid down by Helsinki declaration were duly followed.

\section{ACKNOWLEDGEMENTS}

Dr. Shekh Mohanmmad, Mogli, Gonu, Milind and Meenal.

\section{REFERENCES}

1. World Health Organization. Coronavirus disease (COVID-19) technical guidance: Laboratory testing for 2019-nCoV in humans (Internet). Geneva: World Health Organization; 2020 (updated 2020 Mar 2; cited 2020 Mar 23). Available from: https://www. who.int/emergencies/diseases/novel oronavirus019/technical guidance/laboratory- guidance

2. World Health Organization. WHO announces COVID-19 outbreak a pandemic (Internet). Copenhagen: World Health Organization; 2020 (updated 2020 Mar 12; cited 2020 Mar 28). Available from: http://www.euro.who.int/en/health-topics/healthemergencies/coronavirus-covid19/news/news/2020/3/whoannounces-covid-19-outbreak-a-pandemic

3. BBC India's 1.3bn population told to stay at home. 2020. https:// www.bbc.com/news/world-asia-india-52024239 Retrieved April $3^{\text {rd }} 2020$

4. Almog G, Liebergall M, Tsafrir A, Barzilay $Y$ and Mosheiff R. Management of pelvic fractures during pregnancy. Am J Orthop (Belle Mead NJ) 2007;36(11): E153-E159.

5. Cannada LK, Pan P, Casey BM, Mclntire DD, Shafi S and Leveno KJ. Pregnancy outcomes after orthopedic trauma. J Trauma 2010;69(3):694-698.

https://doi.org/10.1097/TA.0b013e3181e97ed8

https://doi.org/10.1097/TA.0b013e3181ec2b11

6. El Kady D, Gilbert WM, Xing G and Smith LH. Association of maternal fractures with adverse perinatal outcomes. Am J Obstet Gynecol 2006;195(3):711-716.

https://doi.org/10.1016/j.ajog.2006.06.067

7. Ferrer VA, Flores BC and González LS. Transient osteoporosis complicated by a subcapital hip fracture in pregnancy: a clinical case and a literature review. Revespcirortop traumatol 2011;55(3):215-219.

https://doi.org/10.1016/S1988-8856(11)70308-X

8. Lavery JP and Staten-McCormick M. Management of moderate to severe trauma in pregnancy. Obstet Gynecol Clin North Am 1995;22(1):69-90.

9. Greer IA. Thrombosis in pregnancy: updates in diagnosis and management. Hematology Am Soc Hematol Educ Program 2012; 203-207. doi:10.1182/asheducation-2012.1.203 https://doi.org/10.1182/asheducation.V2012.1.203.3798262

10. Tejwani N, Klifto K, Looze $\mathrm{C}$ and Klifto CS. Treatment of Pregnant Patients With Orthopaedic Trauma. J Am Acad Orthop Surg 2017;25(5):e90-e101. https://doi.org/10.5435/JAAOS-D-16-00289

11. Https://www.mohfw.gov.in/pdf/Advisory on the use of Hydroxychloroquinasprophylaxisfor SARSCoV2infection.pdf

12. D'Amico CJ. Trauma in pregnancy. Top Emerg Med 2002; 24:26-39.

13. Singh PK, Shrivastva D, Paddalwar S, Shetty N, Raut V, Patnaik S, et al. Management of maternofetal emergency in shock with fracture of femur. J Surg Tech Case Rep 2011;3(1):52-55. 
https://doi.org/10.4103/2006-8808.78477

14. Harold JA, Isaacson $E$ and Palatnik A. Femoral fracture in pregnancy: a case series and review of clinical management. Int J Womens Health 2019; 11:267-271.

https://doi.org/10.2147/IJWH.S198345
15. Ogbemudia A, Enemudo $\mathrm{R}$ and Edomwonyi E. Closed Interlocked Nailing of A Fractured Femur Without X-Ray Guide In First Trimester Pregnancy: A Case Report. The Internet Journal of Third World Medicine 2006; 5(2).

https://doi.org/10.5580/6fb

Authors Contribution:

AKS, DG, RCM and SK- Concept and design; AKS- Surgical procedure, Manuscript preparation, editing and final approval. DG, MB and RKS- Literature search, Interpretation, analysis, supervision. RCM, MB, RKS and SK- Final approval of manuscript; SK- Manuscript preparation.

Work attributed to:

Department of Orthopedics, SMS Medical College, Jaipur, India.

Orcid ID:

Dr. Arun Kumar Sharma- (D) https://orcid.org/0000-0002-1688-8003

Dr. Divyanshu Goyal- (iD https://orcid org/0000-0001-8893-1878

Dr. Ramesh C Meena- (1) https://orcid.org/0000-0002-8705-6722

Dr. Mahesh C Bansal- (1) https://orcid.org/0000-0003-3308-5760

Dr. Rajesh Kumar Sharma- (D) https://orcid.org/0000-0002-3336-3006

Dr. Sanjeev Kumar- (1) https://orcid.org/0000-0002-8655-9723

Source of support: None, Conflicts of Interest: None 